\title{
La Construcción de "Deseos"
}

\author{
MARINA MAYORAL* \\ Universidad Complutense, Madrid, Spain
}

Me gusta que se hable de mis novelas, que se hable bien, claro, creo que a todo escritor le gusta. E incluso me gustan las críticas cuando son justificadas y no el resultado de una lectura poco atenta. Y no me gusta tener que hablar yo de mis obras. Siempre recuerdo la respuesta de Ingmar Bergman cuando un periodista le preguntó qué había querido decir con su película, Gritos y susurros, una de las más terribles que filmó. El director, con toda seriedad, le dijo que su intención había sido la de pasar un rato agradable con los actores, que eran sus amigos. Si eres alguien tan famoso como Bergman te puedes permitir esa lección, pero yo estoy segura de que, si digo algo así sobre Deseos, el titular de la entrevista sería: "Marina Mayoral la escribió para divertirse un rato", y mucha gente lo creería. En fin, que hay que tener paciencia incluso ante las preguntas más estúpidas.

También recuerdo, siempre cuando tengo que hablar de mis novelas, lo que el padre Isla opinaba (y lo dejó escrito) sobre su obra Historia del famoso predicador fray Gerundio de Campazas, alias Zotes: "Se disputará en las naciones si deja o no deja atrás al famoso Don Quijote". La vanidad del artista es infinita, con escasas excepciones. Cuando acabas una obra a la que has dedicado tanto esfuerzo, tantas horas de tantos años, es normal pensar que

\footnotetext{
* Author's address:

Facultad de Filología

Universidad Complutense de Madrid

E-mail marina@marinamayoral.es
} 
se ha hecho algo bueno, incluso muy bueno, si eres optimista. Yo no lo soy y eso, unido al recuerdo del Padre Isla, me lleva a dar una visión descriptiva de mis obras, prescindiendo de todo criterio de valor literario. Incluso en las contracubiertas de las novelas pido que supriman las expresiones publicitarias y se limiten a resumir el argumento y señalar el carácter humorístico o dramático del engendro.

Pues bien, este preámbulo es para justificar que solo voy a hablar de cómo surgió Deseos y de lo que consideré la mejor forma de contárselo a mis lectores. Es un buen ejemplo de que cada uno vale para lo que vale.

Desde mi niñez fui una contadora de historias, pero no pensaba que eso fuese una vocación o una carrera. Yo quería ser bailarina, y en los ratos libres escultora y pintora, y todavía andan por mi casa algunas zapatillas de ballet y una talla de madera con escenas egipcias, testimonio de mis deseos de entonces y de mi nostalgia actual... A los dieciséis años caí en la cuenta de que aquella capacidad de inventar a partir de cualquier mínima circunstancia o detalle era algo que no podía evitar, que mi cabeza imaginaba al margen de mi voluntad y que además iba aparejada al deseo de contarlo, es decir, de transmitir a los demás aquello que se me había ocurrido. Y descubrí algo más: que los demás pensaban que lo hacía bien. Y desde entonces me dediqué a escribir.

Deseos nació de una frase que oí decir a una mujer: "Tú eres lo único que yo he deseado realmente en la vida". Allí había una novela. Era solo cuestión de dejarla madurar en mi cabeza. Primero sentí curiosidad por saber cómo sería la persona que la había pronunciado e inmediatamente acudieron a mi mente dos posibilidades. Primera: es alguien que ha conseguido todo lo que socialmente se considera deseable: dinero, poder, respeto..., pero que no ha conseguido lo que más ha deseado. Así nació Constanza: hermosa, triunfadora y con una frustración oculta. La otra posibilidad era que fuese alguien con poca suerte en la vida, pero que consigue lo que más desea, aunque la consecución de ese deseo - casarse con el guaperas de la pandilla- se convierta en una fuente de dolor e infelicidad. Así surgió Consu: feíta, bondadosa, sacrificada e infeliz.

Junto a ellas, arrastrados por ellas, surgieron los hombres de su vida: Juanma, el chico guapísimo a quien un accidente lleva al matrimonio con una chica que nunca hubiera elegido de no ser un inválido. Y los hombres de Constanza, que fueron varios, entre ellos el viejo marqués don Pedro Monterroso. Y entre tanto heterosexual apareció de pronto Miguel Ángel, con sus problemas y sus deseos homosexuales, llevando consigo a otra serie de personajes. 
Y junto al deseo erótico, que era el predominante en esas vidas, empezaron a surgir otros deseos encarnados por otros personajes: el deseo de maternidad, el de pervivir a través de la obra artística... Y así surgieron Amalia y con ella Dictino, la persona que ella escoge para realizar su gran deseo de ser madre; su hija Blanquita, que a su vez encarna otros deseos y que trae consigo a su amiga íntima Inés, que es su contrapunto en muchos aspectos, y con Inés aparece Edelmiro, el novio camionero...

El deseo de pervivir a través de la obra literaria se encarnó en Etelvina, un personaje que viene apareciendo en mis novelas desde hace muchos años. Etelvina de Silva está empeñada en que la huella de su paso por el mundo no sean los hijos de su carne, sino los de su invención: sus libros. El ambiente de Deseos era propicio para que apareciese, y apareció y reclamó su espacio. Cuando un personaje se empeña en aparecer hay que dejarle que hable y que actúe, so pena de que fastidie todo el resto. Así que le di cancha a Etelvina y por fin logró rematar la obra que llevaba entre manos desde su adolescencia: La historia de la Braña, de la que ya se hablaba en La única libertad.

Tenía los personajes, y a partir de ahí empieza el trabajo de carpintería. Eran muchos y había que conseguir dar unidad a tantas vidas distintas. Uno de los problemas técnicos de las novelas de muchos personajes es que cada uno tira por su lado y la novela corre el peligro de desparramarse, de convertirse en un conjunto de relatos independientes. Una forma de evitarlo -y esto es el tipo de cosas que se enseñan en los talleres de escritura- es unificarlos mediante el tiempo y el espacio.

Yo los reuní en Brétema, que es mi espacio imaginario, un lugar bastante pequeño como para que la gente se conozca, y bastante grande para que en él se den todos los elementos de la sociedad actual.

En cuanto al tiempo, todo ocurre desde las $6.30 \mathrm{~h}$ de un día hasta la madrugada siguiente.

Otro elemento de cohesión es el paseo matutino de Héctor Monterroso: mucha gente lo ve pasar, y el narrador va presentando a las distintas personas que se preguntan de dónde viene Héctor a esa hora. El procedimiento es tan antiguo como el Lazarillo de Tormes, una estructura de sarta: distintos personajes sucesivos, unidos por la presencia del protagonista. También podría recordar la estructura de La noria de Luis Romero.

El otro problema que se me planteó fue el de las escenas simultáneas: varios personajes están actuando al mismo tiempo en escenarios distintos. La 
simultaneidad en un relato es un problema que no tiene solución. En música dos notas que suenan juntas forman un acorde, pero la palabra no tiene esa facultad: hay que contar sucesivamente, y lo que cuentas primero influye en la percepción de lo que se cuenta después. Por ejemplo: los manejos de Blanquita nos parecen disculpables, y hasta conmovedores, cuando sabemos que Héctor está loco por Constanza. A mí la mejor solución me parece la de Cortázar en "Todos los fuegos, el fuego": ir intercalando trocitos de las dos historias. De esta manera el lector va cambiando su percepción de lo que sucede a medida que recibe más información. A fin de cuentas, eso es lo que sucede también en la vida.

Tenía ya los personajes, el escenario y el tiempo en el que transcurre la acción. Solo quedaba dejarlos vivir: escuchar sus pensamientos y sus conversaciones, seguirlos durante todo un día...Y después contarlo con claridad, precisión y, si es posible, con belleza. Así nació y así se hizo Deseos. 